\title{
Interactive Fountain
}

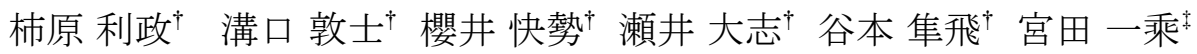 \\ †北陸先端科学技術大学院大学 知識科学研究科 \\ "北陸先端科学技術大学院大学 知識科学教育研究センター \\ 干923-1292 石川県能美市旭台 1-1
}

\begin{abstract}
概要
本論文では, 7 基の噴水を団扇型のコントローラで操るインタラクティブな噴水システムを提案する. 1 基の

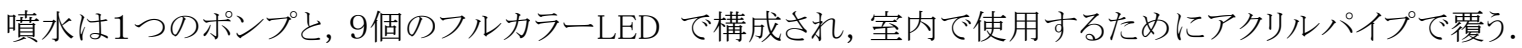
PC は噴水のポンプと LED をコントロールし, 団扇型コントローラの動きにともない水の噴射量と光の色を変 化させる. 団扇の形状が持つアフォーダンスを活用した, インタラクティブな噴水システムを実現した.
\end{abstract}

キーワード：噴水, 加速度センサ, 画像処理, インタラクティブシステム, アフォーダンス

\section{Interactive Fountain}

\section{TOSHIMASA KAKIHARA ${ }^{\dagger}$, ATSUSHI MIZOGUCHI ${ }^{\dagger}, \quad$ KAISEI SAKURAI ${ }^{\dagger}, \quad$ TAISHI SEI ${ }^{\dagger}$, HAYATO TANIMOTO ${ }^{\dagger}$ and KAZUNORI MIYATA ${ }^{\star}$}

${ }^{\dagger}$ School of Knowledge Science, Japan Advanced Institute of Science and Technology

${ }^{\ddagger}$ Center for Knowledge Science, Japan Advanced Institute of Science and Technology

1-1 Asahidai, Nomi, Ishikawa 923-1292 Japan

\begin{abstract}
This paper presents an interactive system which controls fountains. The system consists of seven fountain units; each unit has a PC-controlled water pump and nine full-color LED lights. Each fountain unit pump is is covered with a clear acrylic pipe. The lighting color and jet speed of water are controlled with motion of player's fan. We have installed an interactive fountain system applying an affordance of control fan.
\end{abstract}

Keywords: fountain, acceleration sensor, image processing, interactive system, affordance

\section{1 はじめに}

噴水には様々な目的や機能がある. 水は生命に 不可欠なものであると同時に災いをもたらすもので あるため, 古代人は, オアシス内の湧水を信仰の対 象としていたといら説がある. また, 気化熱による冷 房や, 灌覞用途としての機能もある. 現在の噴水の 多くは観賞用あるいは修景用の装飾物, 環境装置 である. また，人に反応する噴水もある.

本論文では, 直感的な動作で操作できる噴水シス テムを提案し[10], 新たな噴水のあり方を考える. 以 降, 第2章において本研究が対象とする噴水の現状 と課題について触れ, 第3章ではシステムの概要と その技術的な実装について述べる.つづいて第4章 では, 作品を魅力的なものに仕上げるための演出に ついて述べ, 第5章では, 作品の評価実験と考察を しめす. 最後に, 第6章において, まとめと今後の課 題を述べる.

\section{2 研究の背景}

本章では, 本研究の背景と関連研究, および, 研 究の目的について述べる.

\section{1 背景}

アメリカ・シカゴのグラントパークに設置されている バッキンガム噴水や, ラスベガス内のホテルに設置 された噴水など，世界中にはさまざまな噴水が存在 し, また, その中のいくつかは, ライトアップも含めて コンピュータで制御されている. コンピュータ制御に より複数の噴水を統率的に噴射させることで, 噴水 はショーとしてのエンターテイメント性を持つ.

しかし, コンピュータがリアルタイムに噴水を制御し ているとはいえ, コンピュータが一定のスケジュール にしたがって制御するだけでは，古くからの噴水と同 様の, 水を噴射するだけの対話性に乏しい装飾物と いう位置づけになる. 


\section{2 関連研究}

水をテーマにしたメディアアートの研究例には, ラ イトアップしたドーム状の噴水の中に入り五感で楽し める噴水 [6]や, 落下する平面状に並べた水の粒に 光を照射し立体を表示するもの[3], 撥水加工された 布地上に水滴で文字を形成するもの[9]などがある. これらの研究は水や噴水の新たな利用方法を提案 しているが，水の制御に体験者の意思が反映されて いるわけではない。一方, 薄型水槽の底から電磁バ ルブの開閉により気泡を発し, その気泡で文字や図 形を描画する作品[7][8]や，人が近寄ったり手をか ざすと反応する噴水 $[1]$ も存在する.

また，パイプ上に多数開けられた小さな噴水のノ ズルを手で塞ぐと, 関連した音が鳴るインタラクティ ブな噴水 [4][5]も報告されている.これらは，直接噴 水に触れるインタラクションのため, 噴水の操作部は 小型でなければ全体を制御することが出来ない.

\section{3 研究の目的}

以上で述べた現状をふまえ, 本研究では, 操作デ バイスのアフォーダンスを活用した新たな噴水シス テムを提案する.インタラクティブに操作可能な既存 の噴水システムでは，噴水ユニットに直接触れたり， 接近する必要があるために, 体験する噴水の大きさ に制限があったり, 操作の様子を俯瞰することは困 難であつた。

本研究では, 遠隔操作を取り入れることで, 体験 者よりも大きな噴水ユニットを, 操作の様子を鑑賞し ながら直感的に操作することを目的とする. また, 操 作デバイスを工夫することで, 体験者の操作誘導を 容易にすることを目指す。

\section{3 システムの実装}

本章では, はじめにシステムの概要と構成につい て触れ，つづいて，噴水ユニットや団扇型コントロー ラなどの構成要素の実装方法について述べる.

\section{1 システムの概要と構成}

プレイヤは団扇型コントローラを使い, 7 基の噴水 を操作する. 団扇を振るといら単純な動作での操作 であるため, 操作の説明がほとんど不要な, 非言語 依存の操作である.

噴水はプレイヤが操作する団肩型コントローラの 動きに反応し，照明の色を変えながら水を吹き上げ， 天井や噴水の周囲を美しく照らしだす。噴水をプレ イヤの近くに囲むように設置するので水の動きがよく 見え, これまでの遠くから眺める噴水とは違い, 神秘 的な印象を与える. また, コントローラ, および噴水 の動きに対応させて, 鈴の音と水の効果音を鳴らす ことで,より一層神秘的な雰囲気を演出する.
システムは, 図 1 に示すように, 1)PC, 2)団扇型コ ントローラ, 3)CCD カメラ, 4)スピーカ, 5)MIDI 制御 の調光器, 6)噴水ユニット, で構成する.

PC には, 団扇型コントローラのデータを無線で, カメラからの画像データをUSB 接続で入力する.

PC からは, LED の制御信号をシリアル通信で, 調 光器への噴水の制御信号を MIDI 信号で出力する と同時に, スピーカには効果音を出力する.

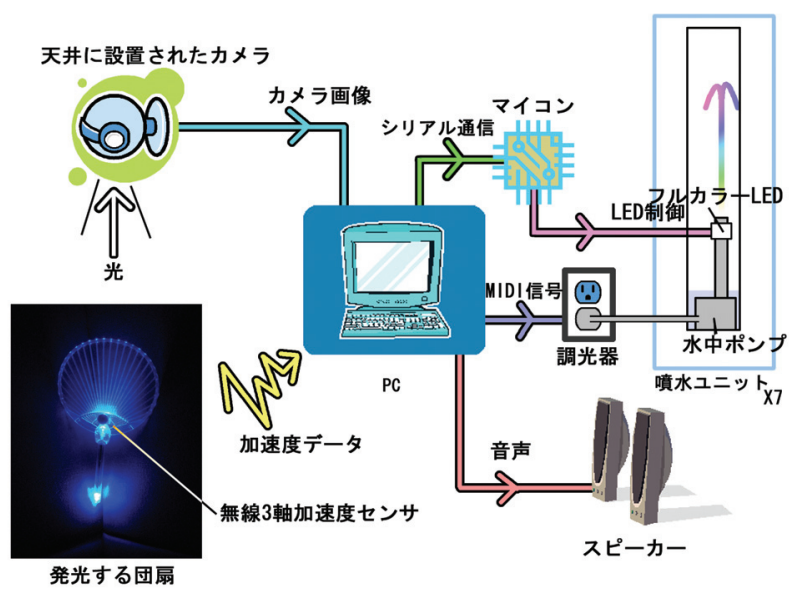

図1 システム構成

\section{2 噴水ユニット}

図 2 に示すように, 水中ポンプ(プティオ製: L25SP-11) に長さ $50 \mathrm{~cm}$ のノズルを取り付けたものを， タライ内部に設置された台に置き，上端部を透明ア クリル板で閉じた半径 $90 \mathrm{~mm}$, 長さ $2000 \mathrm{~mm}$, 厚み $3 \mathrm{~mm}$ の透明アクリルパイプで覆って使用する.

ノズルには, 先端部に金属のノズルヘッドとフルカ ラーLED (Opto Supply 製:OSTA-5131A)を 9 個付 け, 中間部にアクリル製円盤とその上に人工芝を取 り付け固定する.人工芝を水の緩衝材として用いるこ とで，噴射した水がタライに溜まった水に直接着水 することがなくなり, 着水時の気泡による水中ポンプ の動作への悪影響を軽減している. また, アクリルパ イプを高さ $60 \mathrm{~cm}$ の位置でタライと金属ワイヤで固定 し, 電子レンジ用のラップで被覆して防水処理した. さらにこの部分を防水加工された黒い布で覆うことで 水中ポンプやノズルを隠ぺいしている.

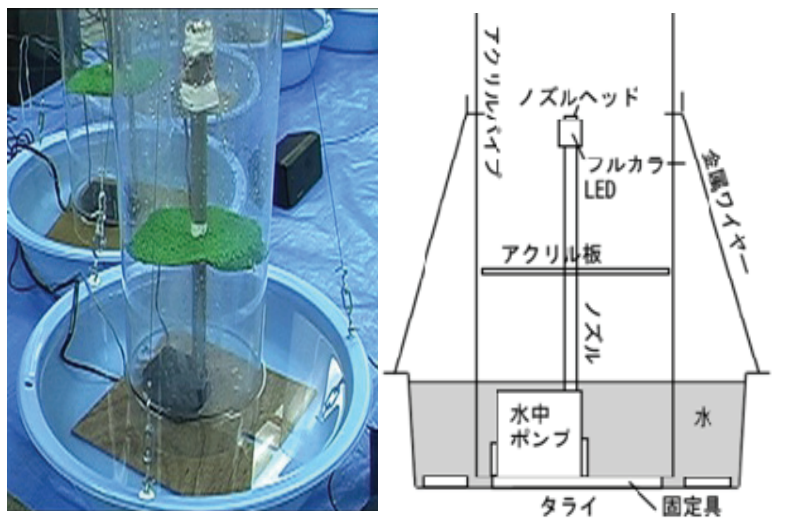

図 2 噴水ユニット 
タライには水中ポンプの作動に十分な水を満たす. 水が重しとなり，噴水ユニットは安定して設置される.

各噴水の噴水量は単体で見たときには迫力に欠 けるが, 図 3 に示寸ように 7 基の噴水を, プレイヤを 囲むように配置することで，十分な迫力を演出できる. 噴水ユニットの水中ポンプは MIDI 調光器を電源 としており, PC からの MIDI 信号によって電源の電 流を変化させることで水中ポンプの出力を制御し, 噴水の高さを変化させている. また, 噴水の高さは 上限と下限を設定しており, 下限の状態では全く水 が出ていない状態ではなく, ある程度出た状態を設 定することで, 噴水の高さを PC からの制御信号に 瞬時に反応させている.

フルカラーLED は, ノズルの先端付近に噴射する 水を照らすように設置する. フルカラーLED は H8 マイコン(ルネサステクノロジ製: H8/3664F) で制御 する. H8 マイコンと PC はシリアル通信で接続し, 各 噴水ユニットにあるフルカラーLED の点灯/消灯を RGB それぞれ独立に制御する。

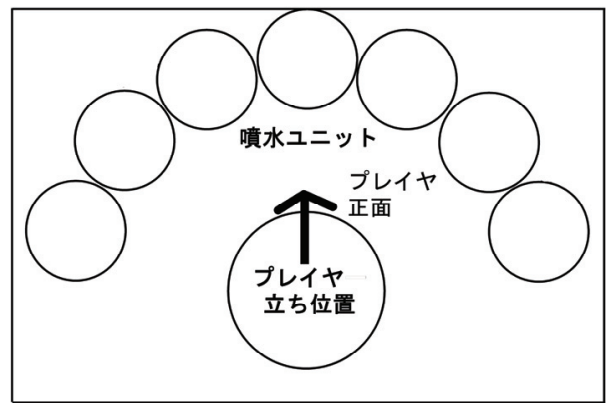

(a) フロアプラン

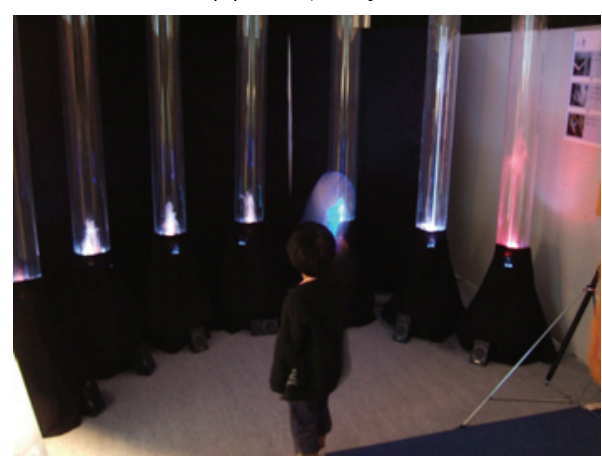

(b) 設置風景

図 3 プレイヤと噴水の配置

\section{3 団扇型コントローラ}

プレイヤが操作するコントローラの母体には, 光る 団扇(マイクロストーン製: S-type)を使用し, 柄の上 の部分に無線 3 軸加速度センサ (日立金属 製:H48C)を取り付けている.

使用した加速度センサは, 重力加速度を $1 \mathrm{G}$ とし た相対的な加速度を, センサの持つ XYZ の各 3 軸 で計測することができる. また, $200 \mathrm{~Hz}$ でサンプリン グしているため, 忘答性が良い. センサの3つのセン
シング軸は, それぞれ図4に示すように団扇の方向 と対応付ける.

団扇型コントローラ(以下, コントローラと呼ぶ)で, 操作動作となる“あおぐ”動作と“斬る”動作をした場 合の加速度の測定結果を図5に示寸.ここで, あお ぐ動作は, 風を送るように団扇の面を動かす動作で ある. 斬る動作は, 団扇の面之同方向（図 4 の $\mathrm{y}$ 軸 方向）に団扇を動か寸動作である. なお，図5のグラ フは, 加速度センサの $\mathrm{xy}$ 軸を水平にして測定したも のである.

本システムでは, $\mathrm{y}$ および $\mathrm{z}$ 軸の加速度の変化の 激しさで動作の判定を行うため, 計測值に含まれる 重力加速度の成分を計測值から引く必要がある.加 速度センサで重力加速度だけを計測するには, 静 止時の計測值を求めればよい.

得られたコントローラの加速度データをサンプル数 20 で平均化したベクトルを“コントローラの動き”, ベ クトルの大きさを”振りの強さ“として, 噴水の高さなど を決定する.

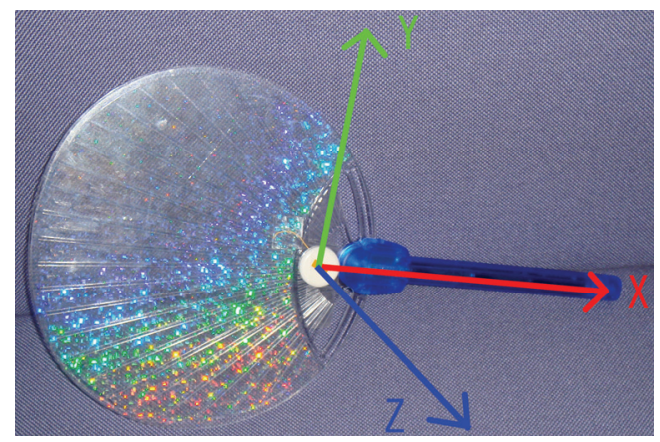

図 4 団扇と加速度センサの対応

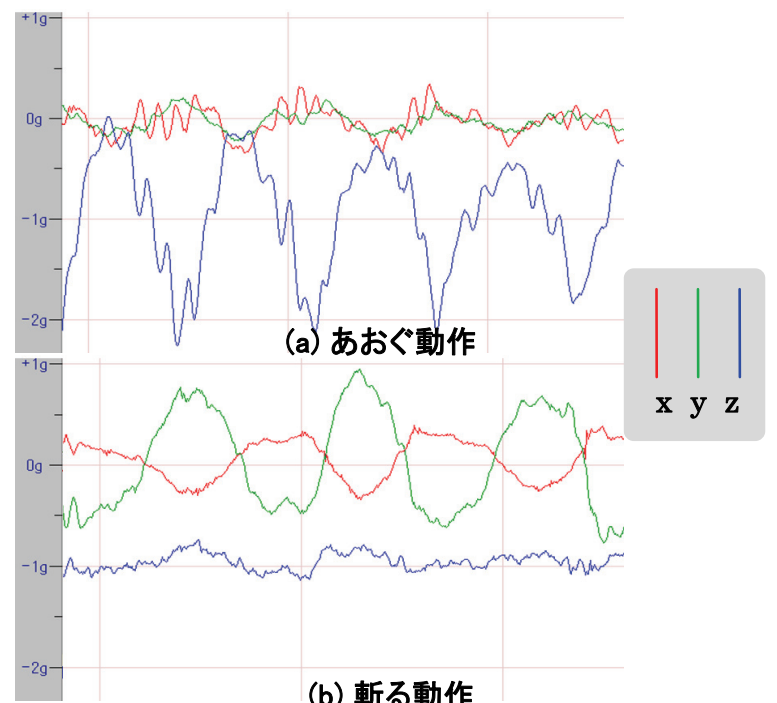

図 5 加速度の測定結果の違い

\subsection{CCD カメラと画像処理}

本節では, 画像処理によるコントローラの位置検 出の方法について述べる. 


\subsubsection{CCD カメラの設置と設定}

CCDカメラ (Logicool製: QVX-13) は，プレイヤの 立ち位置の上部にプレイヤの方向に向けて設置し, コントローラの光源の検出に用いる. なお, 取得する 画像の大きさは, 640 x 480 画素とする. また, 以降 の画像処理に先立ち, 画面内でのプレイヤの立ち 位置, 各噴水ユニットの境界線を設定する. 噴水ユ ニットの境界線の設定では, プレイヤに各噴水の境 界をコントローラで指してもらい, コントローラの向き と境界線が一致するように設定していく. 以上の設 定は, システム設置時に一度だけ行う.

\subsection{2 背景差分による画像抽出}

CCD カメラは, 検出対象のコントローラの光源に 絞って露出を調整することも可能であるが, 噴水ユ ニットにも光源があるため, 運用環境によってはコン トローラの光源以外のものも CCD カメラに映ってし まう可能性がある.このため, どの光源がコントローラ の光なのかを判断する処理が必要である.

本手法では, 背景差分による画像処理を用いてコ ントローラの光源を認識する. すなわち, 操作前にカ メラ画像からコントローラ以外を捉えた画像を背景画 像とし, その後カメラ画像から背景画像を減算するこ とで, コントローラの光のみが映った画像を求め, コ ントローラの位置の判定に使用する. 背景差分の処 理を行った画像の例を図 6 に示す.

背景画像は, カメラからの入力画像に, 各画素の 半径 20 画素の円内にある画素の最大值で, 円内の 各画素を置き換えることで作成する. これにより, 光 源や CCD カメラの移動により背景の位置が多少ず れた場合でも, コントローラの光源だけを残した画像 を求めることができる.

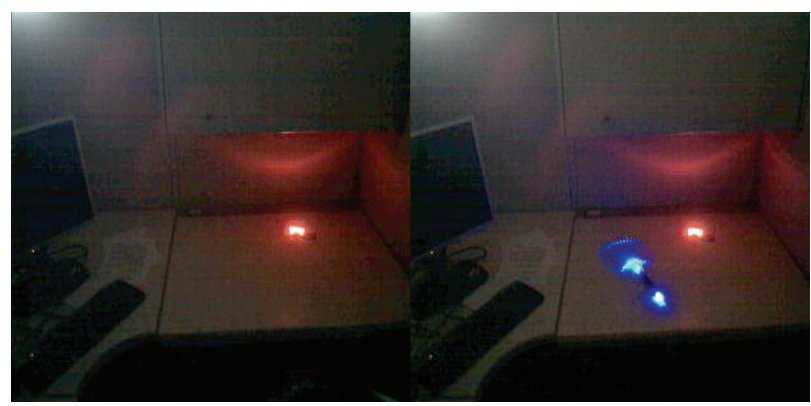

(a) 背景画像

(b) 処理画像

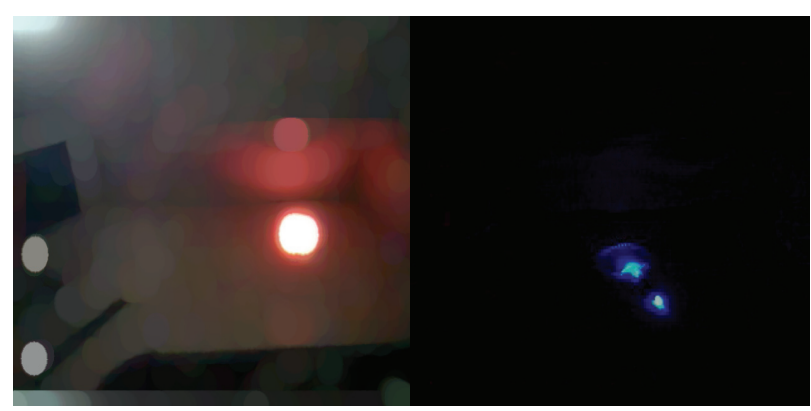

（c）処理後の背景画像 (d) 処理後の光源画像 図 6 画像処理による団扇の光源画像の生成

\subsection{3 コントローラの位置検出}

背景差分で求めた画像に対し，設定した閾值以 上の輝度值を持つ画素をコントローラの光源の画素 とし, それらの画素の位置を平均化した座標值をコ ントローラの光源の位置とする. そして, 設定したプ レイヤの位置とコントローラの光源の位置を結んだ ベクトルをコントローラの向きとし, コントローラが指し 示す噴水を判断する.

\section{4 噴水の演出}

\section{1 コントローラと噴水の動きの対応}

噴水はコントローラを向けると 200 ミ少秒赤く光る. さらにコントローラを振ると, コントローラを向けている 噴水が噴射する.

コントローラの振り方と噴水の対応パターンには, 以下の二種類がある.

（1）面であおぐ: 噴水は青く光り，“振りの強さ”に 応じた高さで一定時間噴射する.

(2) 斬るようにあおぐ: 噴水は緑色に光り, 短い噴 射時間で高く噴射する. また，青く光っている 噴水に斬る操作を行うと, 緑と青を点灯させ, こ れに噴水を指した時の赤を点灯すると噴水は 白く光る.

コントローラの状態は, “あおぐ”, “斬る”, “停止” の 3 種類に分類して判定する.

“停止”の状態とは“振りの強さ”が一定值以下の場 合であり，噴水の噴射を最小にし，団扇型コントロー ラが向けられている噴水を赤く光らせる.

“振りの強さ”が一定以上の場合，“コントローラの 動き“の y 軸と $\mathrm{z}$ 軸を比較し, y 軸が強い場合に”斬 る”, z 軸が強い場合には“あおぐ”, と判定する.

また, コントローラがどの噴水にも向いていない時 は, 噴水の両端のうち, コントローラの光源位置に近 い方の噴水を選択する. さらに, コントローラの光源 を認識できない場合は, 直前に選択した噴水を使用 し，この状態が続いた場合には，噴水をランダムに 選択する.この処理によって, コントローラがカメラの 視野外に移動した場合でも, コントローラを振ること で噴水は反応する.

\section{2 音の演出}

音の演出として, コントローラの動きに合わせた鈴 の音を流す. 鈴の音は, コントローラの“振りの強さ” と, 向けられている噴水によって変化する. 噴水には それぞれ C, D , E , F, G, A, B の 3 和音のコードが 割り当てられており, 表 1 に示すように, 一つの噴水 に対して弱く振れば下の音を, 強く振れば上の音を 鳴らす. また, コントローラが指し示す噴水が変更し た場合は, 必ず弱い振りの音を鳴らす.弱い振りの 音は一番左の噴水から順に音階になっているので, 
コントローラを横に振った場合は, ピアノの鍵盤を順 に弾くような音を鳴らす。

以上のルール付けだけでは, 噴水の選択がラン ダムな場合, 耳障りな音になる可能性がある. この耳 障りな音を解消するため, 噴水の選択が変更された 場合, 音の演出に関してのみ, 右の噴水に変更した 場合は右, 左の噴水に変更した場合は左にしか噴 水の選択を変更できないように, 一定時間の制限を 設ける.

同時に, 鈴以外にも低い長めの音を鈴と同じ処理 で音階を決定し, 出力する. 鈴の音は短い音である ため, 振っている間は細かい間隔で連続して再生さ れるが，同時に流す低めの音は振っている間一定 時間毎に再生する. また, 鈴の音をフェードイン無し で再生するのに対し, 低めの音は振り終わった後, 徐々に聞こえてくるようにフェードインして再生する.

どちらの音も再生スピードを変化させることで様々 な音階の音を再生する. なお, 再生スピード F は式 (1)で求めるものとする.

\section{$\mathrm{F}=\mathbf{M h} * \mathbf{2}^{\wedge}(\mathrm{K}-\mathrm{Mk})$}

ここで, Mh は再生するオリジナルの音声データの再 生スピードで, $\mathrm{K}$ は表 1 に示す音階番号, Mk はオリ ジナルの音声データの音階番号である.

以上の処理で, コントローラの動作に応答させた 音の演出をする.

この他に噴水に対応させた効果音も再生する.こ の効果音は各噴水の出力が最小となったタイミング で数回に一回の割合で, 水泡が割れる音, もしくは 潮の音を再生している. 水泡が割れる音は噴水の出 ていた高さに応じて音量を変えているが, 両方とも 再生スピードをランダムに変更することで, 様々な効 果音を鳴らす.

また, 潮の音はプレイヤの入力がない場合も定期 的に再生する.これらの水に関係した効果音で, プ レイヤの周囲に水が溜まった洞窟のような音空間を 演出することで, 神秘的な雰囲気にしている.

\section{表 1 噴水に割り当てられた音階番号}

\begin{tabular}{|r|r|r|r|r|}
\hline \multirow{2}{*}{ 噴水番号 } & \multirow{2}{*}{ 設定コード } & \multicolumn{3}{|c|}{ 音階番号K } \\
\cline { 3 - 5 } & & 弱い振り & 中間の振り & 強い振り \\
\hline 1 (左端) & $\mathrm{C}$ & 0 & 4 & 7 \\
\hline 2 & $\mathrm{D}$ & 2 & 6 & 9 \\
\hline 3 & $\mathrm{E}$ & 4 & 8 & 11 \\
\hline 4 & $\mathrm{~F}$ & 5 & 9 & 12 \\
\hline 5 & $\mathrm{G}$ & 7 & 11 & 14 \\
\hline 6 & $\mathrm{~A}$ & 9 & 13 & 16 \\
\hline 7 (右端) & $\mathrm{B}$ & 11 & 15 & 18 \\
\hline
\end{tabular}

\section{3 システムの応答性の向上}

CCD カメラを用いたアプリケーションでは，一般に 応答性の悪さが問題となる. 画像処理に GPU を利 用して処理の高速化を試みたが, CCD カメラからの
画像取得の速度が人の動作よりも大幅に遅いため に，画像処理の高速化では応答性の向上には至ら なかった. そこで, 無線3軸加速度センサを組み合 わせることで, システムの応答性の改善を図った. 加 速度センサはサンプリングが非常に高速なため, 応 答性が良い. また, センサユニットは軽量で無線化さ れているため，体験者の動作を制限することがない， といら利点がある.

本システムでは，多少応答性が悪くても支障のな い噴水の選択をカメラで認識し, 応答性が重要な噴 水の噴射制御を加速度センサの計測データに基づ いて行う. CCD カメラからの画像取得は, $30 \mathrm{~Hz}$ 程度 の応答速度であるが，これに画像処理の負荷がか かるため, コントローラの位置検出は実質 $27 \mathrm{~Hz}$ 以 下の応答速度となる. これと比較して, 加速度センサ は $200 \mathrm{~Hz}$ 程度の応答速度となる. システムの構築過 程で, 噴水の噴出量に対する応答性が重要であると 判断し, 噴水の噴出量の制御には加速度センサに よる応答性の向上を試みた. しかし, 加速度センサ のデータに比べカメラ画像は遅れているため, 遅延 時間内のコントローラの“振りの強さ”から最大の強さ の振りを求め，噴水の高さを決定することで応答性と 操作性を向上した。

\section{5 実験結果と考察}

本章では, システムの評価実験と考察, 異文化で の反応，およびシステムの抱える問題点を述べる.

\section{1 評価実験と考察}

2006 年 11 月 10, 11 日に岐阜県各務原市テクノ プラザで開催された IVRC2006 本選大会にて展示 した. その時の展示の様子を図7に示す。

展示の際に評価実験を行い, 48 人の体験者から 付録に示すアンケートを採集した結果を表 2,3 に 示す.なお, アンケートは, 各評価項目を 5 点満点 で主観評価したものである. 作品の評価は, 表 2 に 示すように概ね高評価であった。

また, コントローラには, 3.3 節で述べた団扇型の もの以外に, 図8に示すような棒の先端に白色 LED と加速度センサを付けたステッキ状のものを用意し， コントローラの形状が操作性に与える影響の調査を 行った. この調査は, 以下の理由によるものである. 本システムの制作過程で, 最初は魔法使いをイメー ジし, ステッキ状のもので操作するインタラクションデ ザインとした.この操作デバイスで, IVRC2006 の東 京予選(2006 年 9 月 29,30 日に日本科学末来館に て開催)にて展示を行ったところ, 噴出させたい高さ をステッキで指し示すような操作をする人が多く見受 けられた. そこで, 振りに応じて噴出量を操作するこ とが伝わるようなものを模索し, 最終的に団扇型のコ ントローラにたどりついた. この改良が有効であるか どうかを確かめるために, ステッキ型と団扇型のコン トローラの操作性の比較をした. その結果, 表3に示 

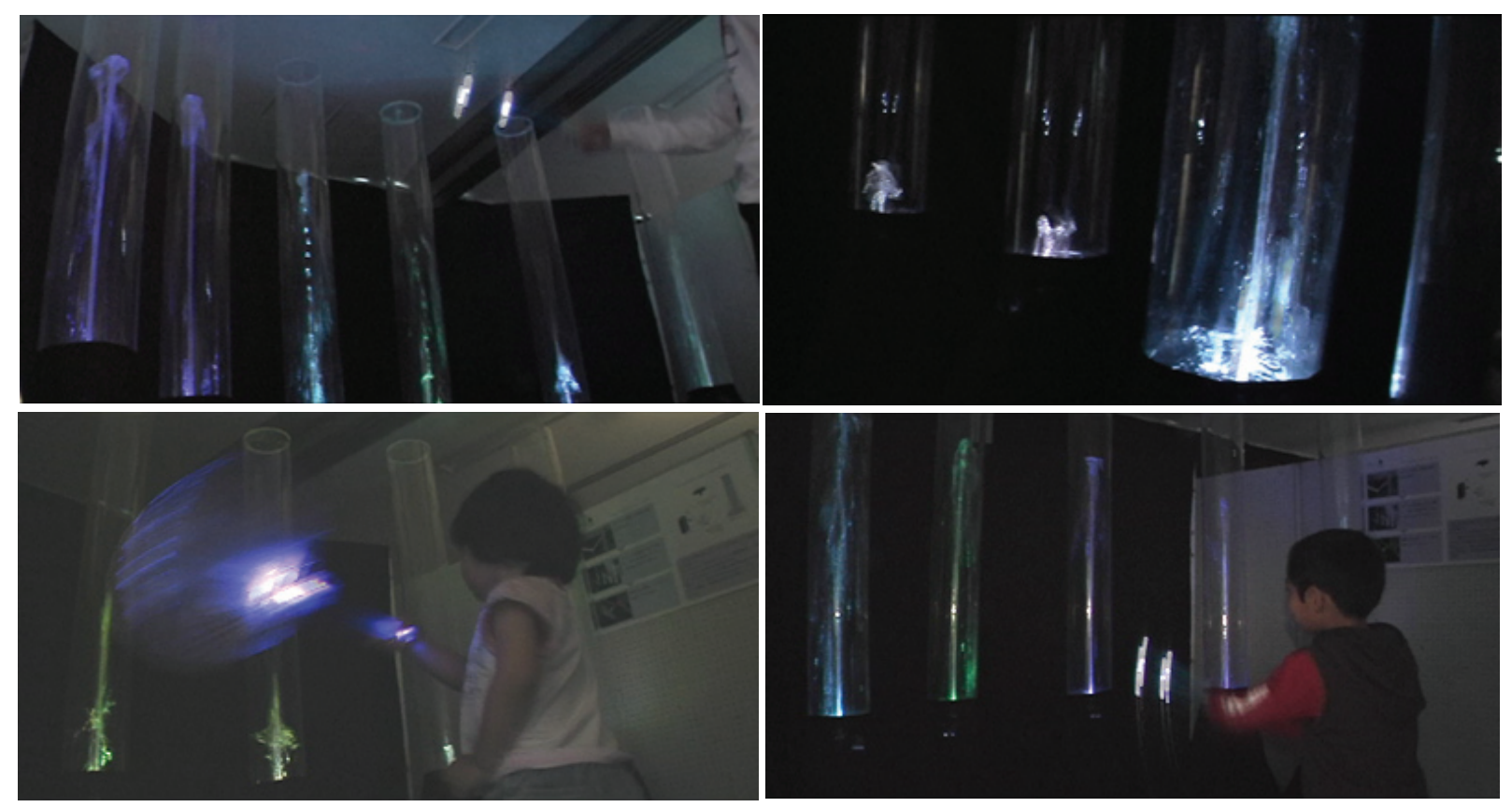

図 7 IVRC2006 本選大会での体験の様子

すように, 団扇型の方が高評価であった. ステッキ状 の場合, 噴水の高さをステッキで指すことで操作す る人がやはり多かった. 実際には加速度で高さを決 めるため, このような操作を想起させる形状のアフォ ーダンスが操作性を悪く感じさせた要因ではないか と考える. 一方, 団扇型では, 水をあおいで勢い付 けるといら操作の意味づけがあるため, ステッキ型と 比較して噴水操作のアフォーダンスに適した形状で あると言える. また, 操作方法が直感的に分かるた め, プレイヤにはほとんど説明の必要がなく, 自由に 体験を楽しんでいたことを確認した。

なお, 審査の結果, 本作品は IVRC2006 にて総 合優勝, 各務原市民賞ならびに, Laval Virtual 賞を 受賞した.

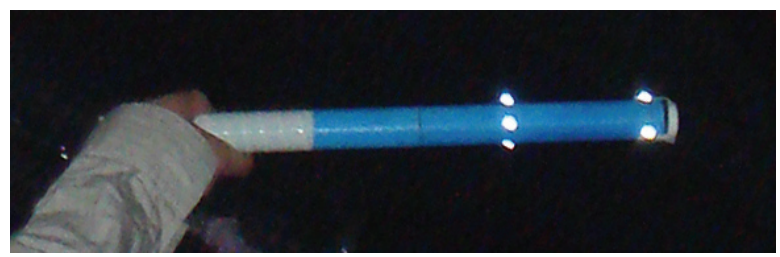

図 8 ステッキ状コントローラ

本システムは, CCD カメラと加速度センサでプレ イヤの動きを計測しているが, CCD カメラはプレイヤ の頭上に設置していた為ほとんどの方が気付かなか った. 加速度センサは団扇型コントローラに設置さ れており隠れてはいなかったが, 体験の場が暗く, 団扇が発光していたためセンサとは認識できなかっ たようである. 結果として, プレイヤにセンサの存在 を陽に感じさせないインタラクションを実現していた のではないかと考える.

懸念していたシステムの応答性であるが, 団扇で あおいだ風が噴水に届いて反応するといらコンセプ
卜を,プレイヤが自然に理解していたために，まった く問題とはならなかった. 実際に, コントローラの振り に対する噴水の応答時間を計測したところ, 最速で 0.03 秒以下, 遅くても 0.1 秒程度であった. 設置の 条件から, 団扇をあおいで発生させた風が, 風速 $5 \mathrm{~m} / \mathrm{sec} \sim 16 \mathrm{~m} / \mathrm{sec}$ (風力 3 の軟風 $\sim 7$ の強風) 程度 で噴水に届いたことに相当する. 応答時間および, 実際の風速に換算した值からも，あおいだ風による 噴水の反応と理解寸るのに妥当な数值と考える.

さらに, どこで噴水を操作してみたいかといらアン ケートを行ったところ, 表 4 のような結果になった. 一 番多かったのが公園で,これは噴水といえば公園を 思い浮かべる人が多かったからではないかと思われ るが, 二番目に多かったホールは, これまでの噴水 の設置イメージとは異なるもののように思われる. 全 体を見るとプライベートな空間である自宅, 庭よりも 公共の空間であるホール, 公園が支持されている. このことから本システムの操作できる噴水が公共の 場に適した提案であったと言える.

表 2 展示アンケート結果 (5 点満点)

\begin{tabular}{|r|r|r|r|r|}
\hline 項目 & 総合評価 & 見た目 & 操作性 & 音楽 \\
\hline 平均 & 4.1 & 4.3 & 3.8 & 3.8 \\
\hline
\end{tabular}

表 3 形状別の操作性アンケート結果 (5 点満点)

\begin{tabular}{|r|r|r|}
\hline 形状 & ステッキ & 団扇 \\
\hline 平均 & 3.6 & 4.3 \\
\hline
\end{tabular}

表 4 やりたい場所のアンケート結果 (複数選択)

\begin{tabular}{|r|r|r|r|r|}
\hline 場所 & 自宅 & ホール & 庭 & 公園 \\
\hline 人数 & 8 & 17 & 13 & 20 \\
\hline
\end{tabular}




\section{2 異文化圈での反応}

本作品は，2007 年 4 月 18 日から 22 日までの 5 日間，フランスの Laval 市で開催された Laval Virtual にて招待展示となった. ただし, 機材の搬送 上の問題から, アクリルパイプを外しての展示となっ た. 困 9 に展示の様子を示す. 以下は, その展示に おける体験者の感想と反応である.

イタリアの宇宙開発のデザイナは, 本作品を新しい ディスプレイだと述べていた。「地球上では考えても 実際に使えないようなデザインでも，月の上や宇宙 では実際にシステムとして動く.だからこそ, 誰も見 たことがないようなデザインが必要だ.この双方向噴 水は，我々が驚くようなデザインを持っている」と言っ ていた. また, パリで芸術家として絵を描いている人 は，「フランスというのは古いものを大切にするけど, こういう光や水を使ったアートもいいものだね. 感動 したよ」とも言っていた. さらに，あるジャーナリストは， 「俺らは歌うのが好きだから, 今度は歌に反応する噴 水作ってくれよ. オーケストラみたいに派手になるの がいいなあ」との感想を漏らした. 美大の学生は, 光 と水を組み合わせて, かつ, 人の動きに反応するこ とに非常に感動していた.これらの感想に共通して いた言葉は, "poetic"であった.

展示中は，ほとんど説明なしにこなすことができた。 噴水の前に立って, らちわを振るだけといら単純な行 動でシステムが反応するので, 他人が遊んでいるの を見るだけで遊び方を理解していたようである.これ は, システムの反応速度が速く, 操作に明確に反応 していることが容易に理解できたといらことにも起因 していると考えられる. 一方で, 終わりが無い作品で あるため, ずっとやり続ける子どもが多く, 人だかりに なることがしばしばあった. また，センサ類を意識す ることなく操作しているため, 周りに電子機器がある ことを忘れて, 水遊びをする人たちもいた。

全体をとおして, 老若男女問わず, かつ，障害(脚 や耳が不自由)を持っている人でも, 滞りなく体験で きていることを確認した.

\section{3 その他の展示}

本作品は, 前述の $2 つ の$ 展示以外に, 財団法人 画像情報教育振興協会主催の第 12 回学生 CG コ ンテストインタラクティブ部門にて佳作入賞を果たし, 2007 年 2 月 24 日から 3 月 4 日まで東京都写真美 術館にて展示した.

また, アジア最大級の規模を誇る映像・情報・通 信の国際展示会である CEATEC にて, 2007 年 10 月 2 日から 6 日までの 5 日間展示を行った. この展 示では, 国内外の来場者 1000 名以上に体験してい ただき, システムの堅牢性も実証することができた。

\section{4 問題点と今後の課題}

\subsection{1 システムの問題点}

現状では, プレイヤによる噴水の選択とコントロー
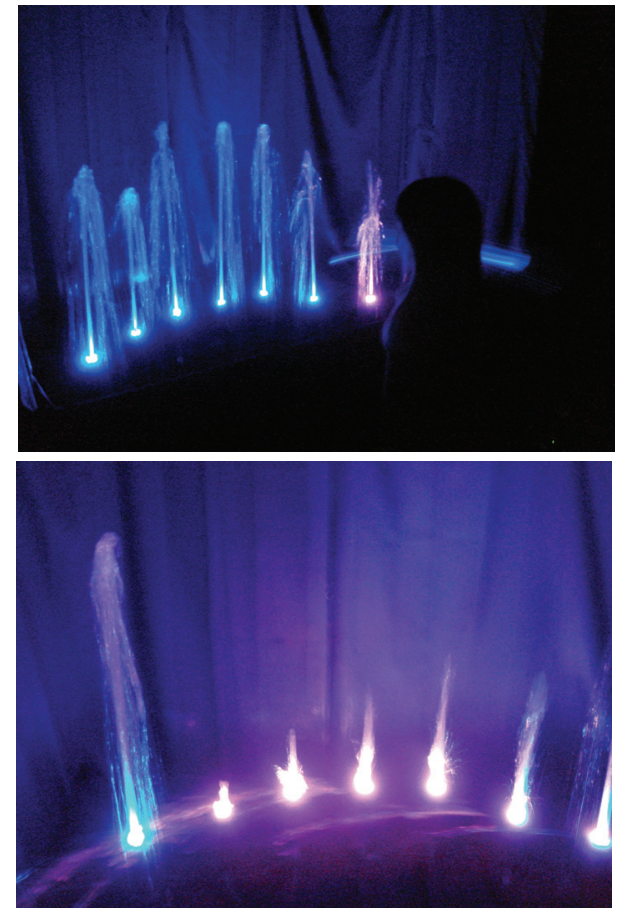

図 9 Laval Virtual での展示の様子

ラの振りの強さしか計測できず, 噴水も高さと色しか 制御できないため, 極論すればコントローラに反応 する応答性が良いだけの噴水になっている. 結果と して,このシンプルな関係が, プレイヤにとつて操作 がわかりやすい, 受け入れやすいものにはなったが， ゲーム性や練習することで上達するような要素を入 れることは出来なかった。

また, 本システムはプレイヤの周囲が暗い環境が 必要であり，昼間の屋外での使用には不向きである. さらに，屋外に設置した場合，CCD カメラの設置が 目立つためにセンサを意識させない操作は困難で ある。

本システムは一人しか体験できない構造であるた め, パブリックな意味を持つ噴水を目指すのであれ ば，大勢で楽しめる存在に改良しないと，その支持 は得られないであろう. 本システムは, 周りの観客も 楽しめるように配慮して開放的な造りにしているが, 複数のプレイヤが同時に体験できるようにしていく必 要がある.

本システムでは, プレイヤからの入力が少なかっ た為, 高さと色の制御だけでも問題はなかったが, プレイヤからの入力を増やし, 多人数のプレイが可 能になった場合, 噴水の表現の幅を拡張する必要 がある.この問題を解決する一つの方法として, 既 存の噴水を利用することが考えられる. いくかの噴 水はコンピュータで制御されているため, 本システム との整合性はよいと考えられる. ただし, 現存する噴 水は, 鑑賞を主目的としたパッケージとして作られて いるため, プレイヤのどの操作に, どのように噴水の 演出を対応付けるか新たにデザインする必要がある. 一方，プレイヤからの入力の増加にともない噴水の 表現の幅を拡張するためには, 噴射の種類や方向 
を制御したりするなどの方法も考えられるが, 装置の 制御機構や大型化が問題となると予想される.

以上挙げた問題点を改善することで, 操作方法と バリエーションの増加にともなった噴水の表現の幅 が拡張され, ゲーム性のような様々な要素を入れる ことが可能になると考える.

\section{4 .2 評価法に関する課題}

5.1 節で示したアンケートは, 体験者の多くが子供 であることが想定されていたために, 必ず回答できる よう簡単なものにした. 評価項目は詳細なものでは なく, また, 主観評価によるものなので, 個人差が出 てしまうことは避けられない. 子供でも簡単に回答で き, かつ客観性の高い評価手法の確立が必要であ る. 例えば, 数名の体験者の行動記録を解析すると ともに, 体験中の思考内容を収録するといら手法が 考えられる. しかし, 行動記録は簡単に取れたとして も, 思考内容は, しばしば用いられる think aloud や, 光卜ポグラフィによる生体計測に基づく評価では, 思 考や感情を阻害したり，子どもには不向きであるとい う欠点がある. エンターテイメントにおけるインタラク ションの評価法に関しては, 非常に大きな研究テー マであり，本論文で扱う範囲を超えていると考えるの で, 今後の課題としたい.

\section{6 まとめ}

以上, 団扇型コントローラの動きで直感的に操作 可能なインタラクティブな噴水を提案した. 今後は 5.4 節で述べた問題点を改善し, より魅力ある噴水と のインタラクションを実現したいと考えている.

また, 本作品は, “人の動作で噴水を操作する”と いらテーマで制作したため, 人の動きと噴水の反応 以外の要素 (例えば気温や風速など) は極力入れな かった. そのため, 噴水を人の動きではない情報に 対応させた場合の検証や, 噴水以外をメインの操作 対象とした場合 (例えば音の変化など)の検証はして いない. 今後, 噴水を音楽に反応させる, 噴水と映 像を組み合わせるなど, 噴水の新たな利用方法の 検討を重ねたい。

\section{謝辞}

研究開発助成をいただいた IVRC 実行委員会 (日 本バーチャルリアリティ学会) 及び, 無線三軸加速度 センサの提供をいただいた日立金属株式会社に深 謝いたします.また, Laval Virtual の展示の際に大 変お世話になった, フランス ENSAM 客員研究員 (現・日本科学末来館)の白井暁彦氏に, この場を お借りし御礼申し上げます。

\section{参考文献}

[1] P.H. Diets, J.Y.Han, J.Westhues, J.B. and W. Yerazunis, "Submerging Technologies,"ACM SIGGRAPH 2006 Emerging technologies, Article No. 30, 2006.

[2] N. Parés, J. Durany, A. Carreras, "Massive flux design for an interactive water installation: water games," Proceedings of the 2005 ACM SIGCHI International Conference on Advances in computer entertainment technology ACE '05, pp.266-269, 2005.

[3] S. Eitoku, K. Hashimoto, T. Tanikawa, Y. Suzuki,

K. Hirota, T. Iwai, and M. Hirose, "Controllable Water Particle Display", Proceedings of the 2006 ACM SIGCHI International Conference on Advances in Computer Entertainment Technology ACE '06, Article No. 36, 2006.

[4] S. Mann, “"fl Huge UId streams": fountains that are keyboards with nozzle spray as keys that give rich tactile feedback and are more expressive and more fun than plastic keys," Proceedings of the 13th annual ACM international conference on Multimedia, pp.181-190, 2005.

[5] S. Mann, R. Janzen, M. Post, "Hydraulophone design considerations: Absement, displacement, and velocitysensitive music keyboard in which each key is a water jet," Proceedings of the 14th annual ACM international conference on Multimedia, pp.519-528, 2006.

[6] Y. Sugihara, "Water display," ACM SIGGRAPH 99 Conference abstracts and applications, pp.183, 1999.

[7] T.Suzuki, S.Ariga and S.Matsumura, "Water Canvas with Ears," http://www.low-tech-ism.com/JWCE.html, 2001

[8] T.Suzuki and S.Matsumura, "Liquid Sculpture," http://www.low-tech-ism.com/ELS.html, 2002

[9] 日本デザインセンター 原デザイン研究所, “Water Logo" (Tokyo Fiber '07 SENSEWARE にて展示)

[10] 柿原, 溝口, 櫻井, 宮田, ”Interactive Fountain”, NICOGRAPH2007 春季大会論文集, セッション I :VR, 2007 


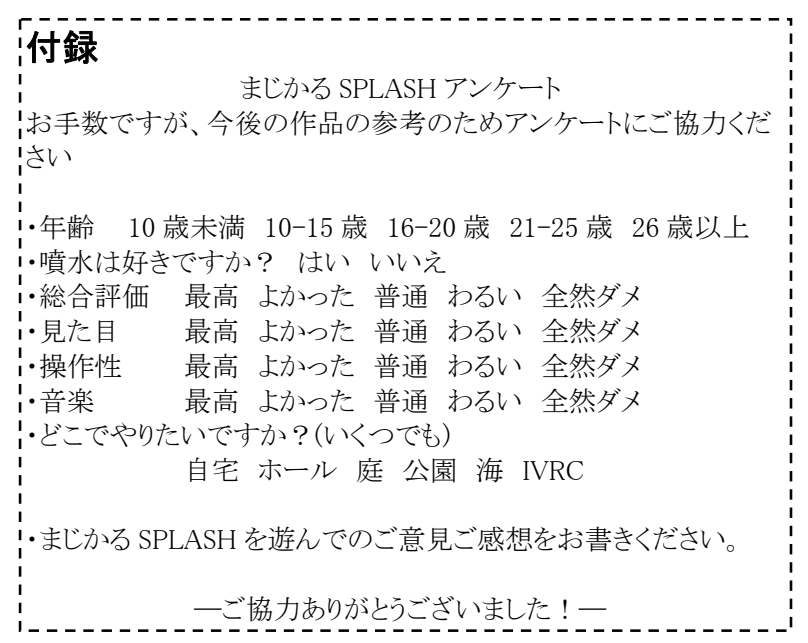

\section{著者略歴}

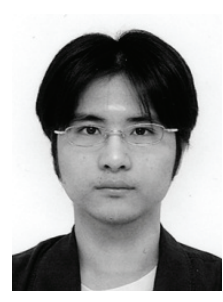

\section{柿原利政}

2006 年京都産業大学計算機科学科 卒. 同年, 北陸先端科学技術大学院 大学知識科学研究科知識科学研究科 博士前期課程入学. コンピュータグラ フィックスに関する研究に従事.

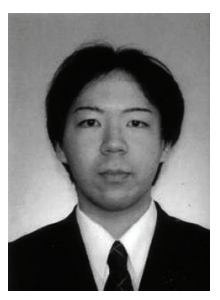

\section{溝口 敦士}

2006 年大阪産業大学機械工学科卒. 同年, 北陸先端科学技術大学院大学 知識科学研究科知識科学研究科博士 前期課程入学. コンピュータグラフィック スに関する研究に従事.

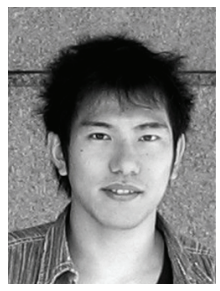

\section{櫻井 快勢}

2006 年 金沢工業大学工学部情報工 学科卒業. 同年, 北陸先端科学技術 大学院大学知識科学研究科博士前期 課程入学. 質感表現の研究に従事. $\mathrm{ACM}$ 学生会員.

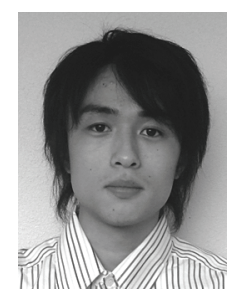

\section{瀬井 大志}

2006 年熊本電波工業高等専門学校専 攻科修了. 同年より北陸先端科学技術 大学院大学知識科学研究科博士前期 課程在学. コンピュータグラフィックスの 研究に従事.

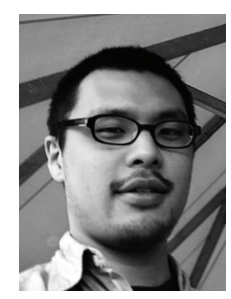

\section{谷本 隼飛}

2006 年近畿大学理工学部卒. 同年, 北陸先端科学技術大学院大学知識科 学研究科知識科学研究科博士前期課 程入学. コンピュータグラフィックスに関 する研究に従事.

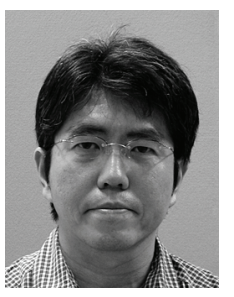

\section{宮田一乘}

1986 年東京工業大学大学院・総合理 工学研究科・物理情報工学専攻修士 課程修了。同年, 日本アイビーエム (株) 東京基礎研究所入社. 1998 年東 京工芸大学芸術学部助教授. 2002 年 より, 北陸先端科学技術大学院大学知 識科学教育研究センター教授. 博士 (工学). コンピュータ グラフィックスおよびデジタル映像表現に関する研究に従 事. 情報処理学会, 芸術科学会, 映像情報メディア学会, ACM, IEEE 等会員. 